\title{
PENERAPAN PEMBELAJARAN AKTIF KOOPERATIF MELALUI METODE NUMBERED HEAD TOGETHER (NHT) SEBAGAI UPAYA MENINGKATKAN AKTIVITAS DAN HASIL BELAJAR IPA - BIOLOGI
}

\author{
Marihot Simanungkalit \\ Sekolah Menengah Atas Negeri 1 Sibolga, Sumatera Utara, \\ marihotsimanungkalit@gmail.com
}

\begin{abstract}
Abstrak: Tujuan penelitian ini adalah: (1) mengetahui hasil penerapan Pembelajaran Kooperatif Metode Numbered Head Together (NHT) pada pembelajaran IPA - Biologi, (2) mengetahui peningkatan hasil belajar IPA - Biologi melalui proses penerapan Pembelajaran Kooperatif Metode NHT, dan (3) mengetahui proses peningkatan keaktifan belajar IPA - Biologi melalui penerapan Pembelajaran Kooperatif Metode NHT siswa. Desain penelitian ini adalah penelitian tindakan kelas dengan subyek penelitian siswa IX SMA Negeri 1 Sibolga sebanyak 38 orang siswa. Penggunaan Pembelajaran Kooperatif Metode Numbered Head Together terbukti dapat meningkatkan penguasaan materi dalam pembelajaran IPA di kelas XI SMA Negeri 1. Penggunaan Pembelajaran Kooperatif Metode NHT dalam pembelajaran mendorong minat dan perhatian siswa dalam mengikuti proses pembelajaran. Siswa menjadi lebih aktif dalam mengikuti pembelajaran, dan bagi guru akan lebih mudah dalam mengajar. Pada pra siklus yang menggunakan metode ceramah bervariasi, ketuntasan belajarnya belum begitu baik yaitu 55,26\%. Adapun pada siklus I dan II yang menggunakan Pembelajaran Kooperatif Metode NHT, menunjukkan peningkatan yang lebih baik yaitu 73,68\% pada siklus I dan 92,11\% pada siklus II. Peningkatan ini juga didukung oleh nilai rata-rata siswa yang naik dari 65,36 pada pra siklus dan menjadi 65,36 pada siklus I, kemudian naik menjadi 76,86 pada siklus II.
\end{abstract}

Kata Kunci: pembelajaran aktif kooperatif, metode numbered head togethe, aktivitas dan hasil belajar IPA biologi

Abstract: The objectives of this study were: (1) to determine the results of the application of Cooperative Learning with the Numbered Head Together (NHT) method in science-Biology learning, (2) to determine the improvement of learning outcomes in Science - Biology through the application process of Cooperative Learning with the NHT Method, and (3) know the process of increasing the activeness of learning Science Biology through the application of cooperative learning with the NHT method for students. The design of this study was a classroom action research with 38 students as research subjects of IX students of SMA Negeri 1 Sibolga. The use of cooperative learning with the Numbered Head Together method is proven to improve the mastery of material in science learning in class XI SMA Negeri 1. The use of cooperative learning The NHT method in learning encourages student interest and attention in following the learning process. Students become more active in participating in learning, and for teachers it will be easier to teach. In the pre-cycle using the varied lecture method, the learning completeness was not very good, namely 55.26\%. As for the first and second cycles using the NHT method of cooperative learning, showed a better improvement, namely $73.68 \%$ in cycle I and $92.11 \%$ in cycle II. This increase was also supported by the student's average score which increased from 65.36 in the pre-cycle to 65.36 in the first cycle, then increased to 76.86 in the second cycle.

Keywords: cooperative active learning, numbered head togethe method, activities and learning outcomes of science - biology

\section{PENDAHULUAN}

Biologi merupakan salah satu cabang sains yang mempelajari tentang seluk beluk makhluk hidup. Pembelajaran biologi tidak harus selalu dengan membaca dan menghafal, tidak pula sekedar interaksi komunikasi dan materi dari guru kepada peserta didik. Pembelajaran biologi harus dapat menciptakan interaksi langsung antara peserta didik dengan objek belajar yang dipelajari yaitu lingkungan. Menurut Suratsih (2010) hakekatnya pembelajaran biologi menekankan adanya interaksi antara peserta didik dengan objek yang dipelajari. Interaksi ini memberi peluang kepada peserta didik untuk berlatih belajar dan mengerti bagaimana belajar, mengembangkan potensi rasional berpikir, keterampilan dan kepribadian serta mengenal permasalahan biologi dan pengkajiannya.

Dalam proses pembelajaran biologi, peserta didik tidak hanya menggunakan buku sebagai sumber belajar, akan tetapi peserta 
didik dapat diarahkan oleh guru untuk mengeksplorasi lingkungan sebagai sumber belajar. Melalui kegiatan belajar langsung di lingkungan, peserta didik diharapkan dapat mengamati dan menemukan sendiri pengetahuannya melalui apa yang mereka amati di lingkungan sekitar, serta memperoleh pengalaman belajar langsung.

Model pembelajaran mempunyai peranan yang cukup besar dalam pembelajaran. Menurut Winatapura (2001) dalam Sugiyanto (2009) model pembelajaran merupakan kerangka konseptual yang melukiskan prosedur yang sistematis dalam mengorganisasikan pengalaman belajar untuk mencapai tujuan belajar tertentu, dan berfungsi sebagai pedoman bagi para perancang pembelajaran dan para pengajar dalam merencanakan dan melaksanakan aktivitas pembelajaran. Kemampuan yang diharapkan dapat dimiliki peserta didik ditentukan oleh kerelevanan penggunaan suatu model pembelajaran yang sesuai dengan tujuan. Hal ini berarti tujuan pembelajaran akan dicapai dengan penggunaan model yang tepat, sesuai dengan standar keberhasilan yang terpatri dalam suatu tujuan. Model yang dapat digunakan dalam kegiatan pembelajaran berbagai macam, penggunaannya tergantung dari perumusan tujuan.

Berbagai macam model pembelajaran untuk peningkatan kualitas proses belajar mengajar salah satunya model pembelajaran kooperatif antara lain Jigsaw, Numbered Heads Together (NHT), Group Investigation, Two Stay Two Stray, Consept Mapping, Think Pair Share (TPS), Make a Match, Listening Team, Inside-Outside Circle, Bambo Dancing, PointCounter-Point, The Power of Two, (Suprijono, 2010).

Pembelajaran IPA perlu melibatkan siswa secara aktif dalam proses pembelajaran yang dilakukan dengan menggunakan tipe-tipe yang mengarah pada student centered, peserta didik diberikan informasi tentang suatu pengetahuan, sikap, atau keterampilan tertentu agar materi tersebut benar-benar terinternalisasi dalam diri siswa.

Pembelajaran yang efektif belum terjadi pada proses pembelajaran IPA di kelas XI SMA Negeri 1 Sibolga, menunjukkan bahwa metode yang digunakan adalah metode ceramah, sebagian besar siswa ramai saat proses pembelajaran, sebagian besar siswa tidak memperhatikan guru yang sedang menyampaikan materi pembelajaran karena penyampaian materi pembelajaran tidak bervariasi atau monoton, sebagian besar siswa kurang aktif dalam proses pembelajaran. Hal ini berakibat pada hasil belajar siswa yang kurang memuaskan. Adapun kelemahan metode ceramah diantaranya: siswa mudah merasa bosan karena guru yang aktif sedangkan siswa pasif, materi yang disampaikan tidak sepenuhnya terserap oleh siswa, menjadikan siswa tidak dapat mengeluarkan kreatifitasnya dan cenderung pasif. Keadaan seperti ini membuat siswa beranggapan bahwa biologi merupakan pelajaran yang membosankan akibatnya siswa tidak termotivasi untuk mempelajari biologi dengan baik sehingga hasil belajar siswa dicapai rendah. Salah satu upaya yang dapat dilakukan untuk memperbaiki kondisi ini adalah dengan melaksanakan Penelitian Tindakan Kelas (PTK). Penelitian Tindakan Kelas (PTK) berasal dari Negara barat yang dikenal dengan istilah Classroom Action Research. PTK merupakan jenis penelitian yang mempunyai tindakan guna menyelesaikan permasalahan yang berasal dari kegiatan pembelajaran di kelas (Arikunto dkk, 2009).

Penelitian tindakan yang dilakukan oleh guru ditujukan untuk meningkatkan situasi pembelajaran yang menjadi tanggung jawabnya yang disebut "Penelitian Tindakan Kelas" atau PTK. Dapat dikatakan bahwa tujuan utama PTK adalah untuk mengubah perilaku pengajaran, perilaku peserta didik dikelas dan mengubah kerangka kerja pelaksanaan pembelajaran di kelas. Jadi PTK lazimnya di maksudkan untuk mengembangkan ketrampilan atau pendekatan baru dalam pembelajaran dan untuk memecahkan masalah dengan penerapan langsung di ruang kelas.

Oleh karena itu, dalam meningkatkan pemahaman dan hasil belajar siswa khususnya pada pokok bahasan ekosistem diperlukan adanya penggunaan model pembelajaran yang tepat. Salah satu model pembelajaran yang tepat untuk diterapkan dalam pembelajaran tersebut yaitu Pembelajaran Kooperatif Metode NHT . Model pembelajaran ini merupakan salah satu dari model kooperatif yang menggunakan struktur kelompok, struktur ini memberikan kesempatan mengembangkan kemampuan berpikir individu. Selain itu Pembelajaran Kooperatif Metode NHT juga memberikan kesempatan bagi siswa untuk mengembangkan kemampuan berpikir, dan berbagi sehingga kemampuan siswa baik secara individu maupun 
kelompok dapat berkembang serta dapat meningkatkan hasil belajar siswa baik dari segi afektif, kognitif maupun psikomotorik guna mencapai tujuan pembelajaran.

\section{Pembelajaran IPA - Biologi}

Definisi tentang IPA (sains) telah banyak dikemukakan, antara lain menurut Supriyadi (2010), para ilmuwan sepakat bahwa IPA adalah suatu bentuk metode yang berpangkal pada pembuktian hipotesa. Sebagian filosof menyatakan bahwa pada hakikatnya IPA adalah jalan untuk mendapatkan kebenaran dari apa yang telah kita ketahui. Dalam Pusat Kurikulum (2006), IPA berkaitan dengan cara mencari tahu tentang alam secara sistematis, sehingga IPA bukan hanya penguasaan kumpulan pengetahuan yang berupa fakta-fakta, konsep-konsep, atau prinsip-prinsip saja tetapi juga merupakan suatu proses penemuan. Trianto (2011) menyatakan pada hakikatnya IPA dibangun atas dasar produk ilmiah, proses ilmiah, dan sikap ilmiah. Dalam sumber yang sama dinyatakan juga bahwa IPA adalah suatu kumpulan teori yang sistematis, penerapannya secara umum terbatas pada gejala-gejala alam, lahir dan berkembang melalui metode ilmiah seperti observasi dan eksperimen serta menuntut sikap ilmiah seperti rasa ingin tahu, terbuka, jujur, dan sebagainya.

Dalam pengelolaan pembelajaran IPA di sekolah, guru harus dapat memberikan pengetahuan peserta didik mengenai konsep yang terkandung dalam materi IPA tersebut. Selain konsep, hendaknya guru dapat menanamkan sikap ilmiah melalui model-model pembelajaran yang dilakukannya. Jadi pelajaran IPA tidak hanya bermanfaat dari segi materinya namun bermanfaat juga terhadap penanaman nilai-nilai yang terkandung ketika proses pembelajarannya.

Untuk belajar IPA diperlukan cara khusus yang disebut dengan metode ilmiah. Metode ilmiah ini menekankan pada adanya masalah, adanya hipotesa, adanya analisa data untuk menjawab masalah atau membuktikan hipotesa, dan diakhiri dengan adanya kesimpulan atau generalisasi yang merupakan jawaban resmi dari masalah yang diajukan.

\section{Hakekat Pembelajaran Aktif Kooperatif Dengan Metode NHT}

Belajar dengan permainan yang dirancang dalam pembelajaran kooperatif memungkinkan siswa dapat belajar lebih santai disamping menumbuhkan tanggung jawab, kejujuran, persaingan sehat dan keterlibatan belajar. Pada hakikatnya cooperative learning sama dengan kerja kelompok. Oleh karena itu, banyak guru yang menyatakan tidak ada sesuatu yang aneh dalam cooperative learning dalam bentuk belajar kelompok. Walaupun sebenarnya tidak semua belajar kelompok dikatakan cooperative learning (Rusman, 2012).

Cooperative learning juga dapat diartikan sebagai suatu struktur tugas bersama dalam suasana kebersamaan diantara sesama anggota kelompok (Solihatin, E., dan Rahardjo dalam Taniredja, 2011).

Model pembelajaran kooperatif tipe NHT atau NHT merupakan model pembelajaran yang dikembangkan oleh Spencer Kagan. Menurut Trianto (2009: 82), NHT merupakan jenis pembelajaran kooperatif yang dirancang untuk mempengaruhi pola interaksi siswa. Sedangkan Huda (2011) menyatakan bahwa model NHT memberikan kesempatan kepada siswa untuk saling membagikan ide-ide dan mempertimbangkan jawaban yang paling tepat dan dapat meningkatkan kerjasama siswa.

Untuk mencapai tujuan aktivitas dan prestasi belajar siswa perlu mengunakan model pembelajaran NHT (Numbered Heads Together). Upaya dalam menerapkan metode diskusi kelompok yang inovatif agar dengan metode diskusi kelompok tersebut semua siswa itu bisa ikut terlibat langsung untuk berpikir dalam memecahkan suatu permasalahan dalam kegiatan diskusi serta tidak terjadi saling mengandalkan satu sama lain diantara anggota kelompoknya sehingga semua siswa akan aktif berpikir dan behasil dalam aktivitas pembelajarannya. Upaya tersebut dapat terwujud dengan cara menerapkan model pembelajaran NHT kepala bernomor struktur (Numbered Heads Together) sebagai inovasi untuk mengaktifkan siswa dalam kegiatan diskusi kelompok. Model Pembelajaran Kooperatif Tipe NHT ini merupakan Pembelajaran kooperatif strategi pembelajaran yang mengutamakan adanya kerjasama antar siswa dalam kelompok untuk mencapai tujuan pembelajaran. Para siswa dibagi ke dalam kelompok-kelompok kecil dan diarahkan untuk mempelajari materi pelajaran yang telah ditentukan. (Nuy, 2011)

\section{Tujuan Pembelajaran Aktif Kooperatif Dengan Metode NHT}


Tujuan dibentuknya kelompok kooperatif NHT (Numbered Heads Together) adalah untuk memberikan kesempatan kepada siswa agar dapat terlibat secara aktif dalam proses berpikir dan dalam kegiatan-kegiatan belajar. Dalam hal ini sebagian besar aktivitas pembelajaran berpusat pada siswa, yakni mempelajari materi pelajaran serta berdiskusi untuk memecahkan suatu masalah. Ibrahim (2000) mengemukakan tiga tujuan yang diharapkan tercapai dalam pembelajaran kooperatif dengan tipe NHT yaitu:

a. Prestasi belajar akademik stuktural, ini bertujuan untuk meningkatkan kinerja siswa dalam tugas-tugas akademik.

b. Pengakuan adanya keragaman, ini bertujuan agar siswa dapat menerima teman temannya yang mempunyai berbagai latar belakang yang berbeda.

c. Pengembangan keterampilan sosial, ini bertujuan untuk mengembangkan keterampilan sosial siswa.

Keterampilan yang dimaksud antara lain berbagi tugas, aktif bertanya, menghargai pendapat orang lain, mau menjelaskan ide atau pendapat, bekerja dalam kelompok dan sebagainya.

Struktur NHT sering disebut berpikir secara kelompok. NHT digunakan untuk melibatkan lebih banyak siswa dalam menelaah materi yang tercakup dalam suatu pelajaran tersebut. NHT sebagai model pembelajaran pada dasarnya merupakan sebuah variasi diskusi kelompok. Adapun ciri khas dari NHT adalah guru menunjuk seorang siswa yang mewakili kelompoknya. Dalam menunjuk siswa tersebut, guru tanpa memberi tahu terlebih dahulu siapa yang akan mewakili kelompok tersebut. Dalam implementasinya guru memberi tugas dalam bentuk LKS, kemudian hanya siswa bernomor yang berhak menjawab (mencegah dominasi tertentu). Dengan demikian, model pembelajaran kooperatif tipe Numbered Heads Together (NHT) dapat diartikan sebagai salah satu tipe pembelajaran kooperatif yang menekankan pada struktur khusus yang dirancang untuk mempengaruhi pola interaksi siswa dan memiliki tujuan untuk meningkatkan penguasaan akademik melalui diskusi yang terdiri kelompok-kelompok kecil yang heterogen, serta kesiapan siswa saat dipanggil nomor-nomornya oleh guru untuk mengetahui pemahaman siswa terhadap materi yang disampaikan.

\section{Langkah-Langkah Pembelajaran Kooperatif Metode $\mathrm{NHT}$}

Pelaksanaan pembelajaran dengan model pembelajaran kooperatif tipe NHT agar dapat berjalan dengan efektif, ada beberapa langkah yang perlu dilakukan dalam merencanakan dan menyiapkan pembelajaran. Anita Lie (2004) yaitu:

a. siswa dibagi dalam kelompok, setiap siswa dalam setiap kelompok mendapatkan nomor,

b. guru memberikan tugas dan masing-masing kelompok mengerjakannya,

c. kelompok memutuskan jawaban yang dianggap paling benar dan memastikan setiap anggota kelompok mengetahui jawaban ini,

d. guru memanggil salah satu nomor, siswa dengan nomor yang dipanggil melaporkan hasil kerjasama mereka.

Selanjutnya, Agus Suprijono (2011: 92) mengemukakan bahwa, pembelajaran dengan menggunakan model Numbered Heads Together diawali dengan numbering. Guru membagi kelas menjadi kelompokkelompok kecil. Setiap anggota kelompok diberi nomor sesuai dengan jumlah anggota kelompok. Setelah terbentuk kelompok, maka guru mengajukan pertanyaan yang harus dijawab oleh setiap kelompok, selanjutnya guru memberikan kesempatan kepada masingmasing kelompok untuk menyatukan kepalanya "Heads Together" berdiskusi memikirkan jawaban atas pertanyaan guru.

Langkah selanjutnya, guru memanggil siswa yang bernomor sama dari masing-masing kelompok. Siswa-siswa tersebut diberi kesempatan untuk menyampaikan hasil diskusinya, secara bergantian. Berdasarkan jawaban-jawaban tersebut guru dapat mengembangkan diskusi dan siswa dapat menemukan jawaban pertanyaan dari guru sebagai pengetahuan yang utuh.

Kegiatan guru dalam proses pembelajaran dengan NHT berdasarkan pendapat tokoh di atas, dapat dirangkum sebagai berikut:

a. Membagi siswa ke dalam kelompok kecil (4-6 siswa) yang heterogen.

b. Membagikan nomor kepada setiap anggota kelompok sesuai dengan jumlah kelompok.

c. Guru mengajukan pertanyaan kepada siswa dan memberikan kesempatan kepada siswa untu berdiskusi pada kelompoknya.

d. Guru memanggil salah satu nomor, siswa yang merasa nomornya dipanggil oleh guru 
diberi kesempatan untuk menyampaikan hasil diskusinya.

e. Berdasarkan jawaban-jawaban siswa guru mengembangkan diskusi dan siswa dapat menemukan jawaban atas pertanyaan dari guru sebagai pengetahuan utuh.

Tujuan penelitian dan pengembangan ini adalah sebagai berikut: (1) mengetahui hasil penerapan Pembelajaran Kooperatif Metode NHT (NHT) pada pembelajaran IPA - Biologi, (2) mengetahui peningkatan hasil belajar IPA Biologi melalui proses penerapan Pembelajaran Kooperatif Metode NHT, dan (3) mengetahui proses peningkatan keaktifan belajar IPA Biologi melalui penerapan Pembelajaran Kooperatif Metode NHT siswa.

\section{METODE}

Penelitian ini merupakan penelitian tindakan kelas (classroom action research). Penelitian tindakan kelas yang dimaksud adalah "kajian sistematik dari upaya perbaikan pelaksanaan praktek pendidikan oleh sekelompok guru dengan melakukan tindakantindakan dalam pembelajaran, berdasarkan refleksi mereka mengenai hasil dari tindakantindakan tersebut". Penelitian ini menggambarkan penelitian tindakan sebagai "suatu proses siklikal spiral yang meliputi beberapa langkah yaitu perencanaan, pelaksanaan dan pengamatan". Penelitian ini dilaksanakan di kelas XI SMA N 1 Sibolga, Kota Sibolga, Sumatera Utara, yang merupakan Sekolah Menengah Atas Negeri dibawah ruang lingkup dinas pendidikan Kota Sibolga.

\section{Siklus Penelitian}

Siklus penelitian tindakan kelas ini terdiri dari 4 tahap. Secara rinci digambarkan sebagai berikut:

\section{Pra Siklus}

a. Perencanaan:

1) Merencanakan (RPP)

2) Menyusun Kuis.

b. Tindakan dengan menerapkan tindakan yang mengacu pada skenario dan lembar observasi siswa meliputi:

1) Guru membuka pembelajaran

2) Guru menerangkan materi kerajaan hindu

3) Siswa dipersilahkan untuk bertanya

4) Guru Menyimpulkan materi

5) Guru menutup pembelajaran

c. Observasi dengan melakukan format observasi
Tahap ini dilaksanakan observasi terhadap pelaksanaan tindakan dengan menggunakan observasi yang telah dipersiapkan. Peneliti mempersiapkan lembar observasi yang telah disiapkan untuk mengetahui kondisi kelas terutama keaktifan belajar siswa dalam pembelajaran. Penelitian ini hasil pengamatan kemudian dicari solusi dari permasalahan yang ada pada waktu pembelajaran berlangsung

d. Refleksi

1) Menilai hasil tindakan.

2) Melakukan evaluasi tindakan yang telah dilakukan.

3) Melakukan pertemuan untuk membahas hasil evaluasi tentang skenario model pembelajaran, nilai dan lain-lain.

4) Memperbaiki pelaksanaan tindakan sesuai hasil evaluasi untuk digunakan pada siklus berikutnya.

\section{Siklus I}

a. Perencanaan:

1) Merencanakan (RPP)

2) Menyusun Kuis.

3) Menyusun LOS (Lembar Observasi Siswa)

b. Tindakan dengan menerapkan tindakan yang mengacu pada skenario dan LOS meliputi:

1) Guru membuka pembelajaran

2) Guru menyampaikan topik materi kerajaan Budha.

3) Guru memberikan tugas kepada peserta didik untuk menjawab beberapa permasalahan.

4) Guru meminta kepada peserta didik secara berpasangan untuk menjawab secara berpasangan (dua orang).

5) Setelah peserta didik yang bekerja berpasangan tadi mendapatkan jawaban, pasangan tadi digabungkan dengan pasangan disampingnya. Dengan ini terbentuk kelompok dengan anggota empat orang.

6) Kelompok berempat ini mengerjakan tugas yang sama seperti dalam kelompok dua orang. Dalam langkah ini perlu ditegaskan bahwa jawaban kedua kelompok harus disepakati oleh semua anggota kelompok baru.

7) Setelah kelompok berempat ini selesai mengerjakan tugas, setiap kelompok digabungkan dengan satu kelompok yang lain. Dengan itu muncul kelompok baru 
yang anggotanya delapan orang. Yang dikerjakan oleh kelompok baru ini sama dengan tugas pada langkah kelima di atas.

8) Masing-masing kelompok diminta menyampaikan hasilnya di depan kelas.

9) Guru membandingkan jawaban dari masing- masing kelompok kemudian memberikan ulasan- ulasan dan penjelasan- penjelasan

10) secukupnya sebagai klarifikasi dari jawaban peserta didik.

11) Penutup

c. Observasi dengan melakukan format observasi

Tahap ini dilaksanakan observasi terhadap pelaksanaan tindakan dengan menggunakan observasi yang telah dipersiapkan. Peneliti mempersiapkan lembar observasi yang telah disiapkan untuk mengetahui kondisi kelas terutama keaktifan belajar siswa dalam pembelajaran. Penelitian ini hasil pengamatan kemudian dicari solusi dari permasalahan yang ada pada waktu pembelajaran berlangsung.

\section{d. Refleksi}

1) Menilai hasil tindakan dengan menggunakan format LOS.

2) Melakukan evaluasi tindakan yang telah dilakukan.

3) Melakukan pertemuan untuk membahas hasil evaluasi tentang skenario model pembelajaran, LOS, dan lain-lain.

4) Memperbaiki pelaksanaan tindakan sesuai hasil evaluasi untuk digunakan pada siklus berikutnya.

\section{Siklus II}

Setelah melakukan evaluasi tindakan I, maka dilakukan tindakan II. Peneliti mengamati proses penerapan Pembelajaran Kooperatif Metode NHT pada pembelajaran IPA - Biologi yang berlangsung di dalam kelas. Langkahlangkah siklus II adalah sebagai berikut:

\section{Perencanaan}

1) Membuat RPP.

2) Menyusun Kuis.

3) Menyusun LOS (Lembar Observasi Siswa)

\section{Pelaksanaan tindakan}

Kegiatan yang dilaksanakan tahap ini yaitu Pengembangan rencana tindakan II dengan melaksanakan tindakan upaya lebih meningkatkan semangat belajar siswa dalam proses penerapan Pembelajaran Kooperatif Metode NHT pada pembelajaran IPA - yang telah direncanakan.

\section{Observasi}

Peneliti mempersiapkan lembar observasi yang telah disiapkan untuk mengetahui kondisi kelas terutama keaktifan belajar siswa dalam pembelajaran. Penelitian ini hasil pengamatan kemudian dicari solusi dari permasalahan yang ada pada waktu pembelajaran berlangsung.

\section{Refleksi}

1) Menilai hasil tindakan dengan menggunakan format LOS.

2) Melakukan evaluasi tindakan yang telah dilakukan.

3) Menganalisis hasil pengamatan untuk memperoleh gambaran bagaimana dampak dari tindakan yang dilakukan hal apa saja yang perlu diperbaiki sehingga diperoleh hasil refleksi kegiatan yang telah dilakukan.

4) Melakukan pertemuan untuk membahas hasil evaluasi tentang skenario model pembelajaran, LOS, dan lain-lain.

5) Memperbaiki pelaksanaan tindakan sesuai hasil evaluasi untuk digunakan pada siklus berikutnya.

\section{Teknik Pengumpulan Data}

\section{Metode Observasi}

Metode observasi merupakan suatu proses yang kompleks, suatu proses yang tersusun dari berbagai proses biologis dan psikologis. Teknik pengumpulan data dengan observasi digunakan bila penelitian berkenaan dengan akhlak manusia, proses kerja, gejala-gejala alam dan bila responden yang diamati tidak terlalu besar. Metode pengamatan (observasi) adalah "cara pengumpulan datanya terjun langsung ke lapangan terhadap objek yang diteliti, populasi (sampel)".

Dalam kegiatan ini yang diobservasi secara langsung adalah aktivitas siswa dan kinerja guru ketika proses penerapan Pembelajaran Kooperatif Metode NHT pada pembelajaran IPA dengan menggunakan format lembar observasi siswa. Bentuk keaktifan siswa yang diamati dalam penelitian ini diantaranya:

1) Siswa Aktif Mendengarkan guru

2) Siswa Aktif bertanya

3) Siswa aktif dalam kerja Individual

4) Siswa Aktif dalam kerja $N H T$

5) Siswa aktif mengomentari kelompok lain

\section{Metode Tes}

Metode tes merupakan "seperangkat rangsangan (stimulus) yang diberikan kepada seseorang dengan maksud untuk mendapatkan jawaban yang dapat dijadikan dasar bagi penentu skor angka". Metode tes ini digunakan 
untuk mengetahui skor nilai melalui angka yang diberikan kepada siswa terhadap jawaban soal tes yang diberikan setelah melakukan tindakan untuk mengetahui hasil belajar siswa. Tes ini merupakan evaluasi tertulis pilihan ganda untuk mengetahui hasil belajar siswa baik pra siklus maupun tindakan siklus.

\section{Metode Dokumentasi}

Metode dokumentasi dari asal katanya "dokumen yang artinya barang-barang tertulis". Sumber dokumentasi pada dasarnya merupakan segala bentuk sumber informasi yang berhubungan dengan dokumen baik resmi maupun yang tidak resmi. Metode ini digunakan untuk memperoleh data siswa.

\section{Teknik Analisis Data}

Teknik analisis data merupakan unsur yang sangat penting dalam setiap kali melakukan penelitian. Semua data yang telah terkumpul tidak akan berarti kalau tidak diadakan penganalisaan. Hasil dari penganalisaan akan memberikan gambaran, arah serta tujuan dan maksud penelitian.

Penelitian ini menggunakan analisis statistik sederhana, yaitu dengan analisis deskriptif kuantitatif dan kualitatif. Analisis deskriptif kuantitatif adalah model analisis dengan cara membandingkan rata-rata prosentasenya, kemudian kenaikan rata-rata pada setiap siklus. Disini yang dianalisis yaitu tentang hasil ulangan pada tiap siklus. Dari hasil ulangan tersebut, dapat ditafsirkan tentang ketuntasan belajar siswa. Dalam penelitian ini untuk ketuntasan belajar siswa individu maupun klasikal digunakan pedoman ketuntasan siswa, sebagai berikut:

a. Ketuntasan Perorangan: Seorang siswa dikatakan berhasil (mencapai ketuntasan) belajar bila telah mencapai taraf penguasaan minimal 70\% atau dengan nilai 65-70.

b. Ketuntasan Klasikal: Suatu kelas dikatakan telah berhasil (mencapai ketuntasan belajar) jika paling sedikit $80 \%$ data jumlah siswa dalam kelas tersebut telah mencapai ketuntasan perorangan.

Analisis deskriptif kualitatif adalah model analisis dengan cara memberikan data yang berupa informasi dalam bentuk kalimat yang memberi gambaran ekspresi siswa tentang tingkat pemahaman terhadap suatu mata pelajaran (kognitif), pandangan atau sikap siswa terhadap metode belajar yang baru (afektif), aktivitas siswa pada saat mengikuti pelajaran, perhatian, antusias dalam belajar, kepercayaan diri, motivasi belajar dan sejenisnya.

\section{Indikator Keberhasilan}

Data-data yang diperoleh dari penelitian baik melalui pengamatan, tes atau dengan menggunakan metode yang lain kemudian diolah dengan analisis deskriptif untuk menggambarkan keadaan peningkatan pencapaian indikator keberhasilan tiap siklus dan untuk menggambarkan keberhasilan belajar pelaksanaan Pembelajaran Kooperatif Metode NHT pada mata pelajaran IPA - Biologi (IPA) di kelas XI SMA Negeri 1 Sibolga. Adapun tehnik pengumpulan data yang berbentuk kuantitatif berupa data-data yang disajikan berdasarkan angka-angka maka analisis yang digunakan yaitu presentase dengan rumus sebagai berikut:

$$
\text { Nilai }=\frac{\text { Skor yang dicapai }}{\text { Skor maksimal }} \times 100 \%
$$

Keseluruhan data yang dikumpulkan digunakan untuk menilai keberhasilan tindakan dengan indikator keberhasilan yaitu untuk Meningkatnya penguasaan pembelajaran IPA Biologi pada siswa kelas XI SMA Negeri 1 Sibolga melalui penerapan Pembelajaran Kooperatif Metode NHT .

\section{HASIL DAN PEMBAHASAN \\ Hasil Pelaksanaan Penelitian Pelaksanaan Siklus I}

Pelaksanaan siklus I . ini dilakukan pada bulan Februari 2018, siklus I ini terdiri dari beberapa tahapan diantaranya: Perencanaan. Pada tahap perencanaan ini peneliti mempersiapkan: Menyusun RPP, Menyusun tes, Menyiapkan lembar kerja siswa. Menyiapkan lembar observasi,Menyusun kelompok, Pendokumentasian.,

\section{Tindakan}

Peneliti memulai proses pembelajaran pada siklus I ini dengan mengucapkan salam dan mengajak semua siswa untuk berdo'a bersama, mengabsensi siswa, menghubungkan pelajaran yang lalu dengan yang sekarang dengan kegiatan tanya jawab. Selanjutnya Siswa mencari informasi tentang materi pembelajaran IPA dengan membaca buku dan memperhatikan penjelasan dari guru. Kegiatan dilanjutkan guru memberikan lembar kerja pembelajaran IPA yang di kasih tanda titik-titik untuk di isi dan di diskusikan oleh anggota kelompok. Dalam hal ini siswa belajar secara kooperatif. 
Kegiatan dilanjutkan guru menekankan siswa untuk membaca dan meneliti dengan seksama bukunya agar bisa menjawab lembar kerja siswa tersebut, kegiatan dilanjutkan guru dan siswa membahas LKS tersebut dengan menanyakan jawabannya kepada siswa dan siswa lain mengomentari. Setelah diskusi selesai guru mengklarifikasi hasil kerja siswa secukupnya dan memberikan kuis kepada setiap pertanyaan yang dibuat oleh guru, dimana sumber kuis dibuat guru berdasar LKS dan buku ajar. Pada tahapan terakhir yaitu penutup dimana guru menyuruh siswa untuk mengumpulkan hasil kuis kedepan dan mengajak do'a bersama.

\section{Observasi}

Setelah mengobservasi siswa selama proses pembelajaran Metode Kooperatif $N H T$ di kelas dengan menggunakan instrumen observasi terkait keaktifan siswa dalam mendengarkan dengan seksama penjelasan guru, keaktifan siswa dalam melengkapi jawaban, keaktifan siswa dalam membaca jawaban dan keaktifan siswa dalam mengomentari hasil kerja teman.

\section{Refleksi}

Dari hasil di atas ada beberapa kekurangan guru dalam melaksanakan pembelajaran diantaranya:

1) Guru kurang dapat menjelaskan Metode Kooperatif NHT yang dilakukan, guru menjelaskan materi terlalu cepat

2) Guru kurang dapat menyetting kelas yang memungkinkan siswa dapat berkomunikasi dengan siswa secara kooperatif

3) Guru lebih banyak di depan,

4) Guru kurang dapat memanfaatkan media pembelajaran dan memvariasi dengan metode lain untuk memperjelas materi dan menarik minat belajar siswa

5) Siswa belajar secara individual masih kesulitan dalam menjawab LKS.

Di akhir kegiatan peneliti melakukan refleksi dengan mengevaluasi kegiatan yang ada di siklus I, mencari solusi terhadap permasalahan yang ditemukan di kelas diantaranya:

1) Menjelaskan lagi pembelajaran Metode Kooperative NHT yang dilakukan

2) Menjelaskan materi lebih detail lagi dengan menggunakan ekspositori

3) Menggunakan media audio visual yang peneliti dapat dari internet untuk memperjelas materi pembelajaran

4) Membuat setting kelas dengan formasi $U$ yang dapat menjadikan siswa menjadi aktif.

5) Membentuk kelompok belajar siswa.
Hasil refleksi di atas dapat dijadikan sebagai rumusan untuk diterapkan pada siklus II sebagai upaya perbaikan terhadap pelaksanaan siklus I.

\section{Pelaksanaan Siklus II}

Pelaksanaan siklus II ini dilakukan pada bulan Maret 2018. Siklus II ini terdiri dari beberapa tahapan diantaranya:

\section{Perencanaan:}

Pada tahap perencanaan ini peneliti menyiapkan: Menyusun RPP , Menyiapkan tes , Menyiapkan lembar observasi , Membentuk kelompok, Menyetting kelas huruf U, Menyiapkan media audio visual,

Pendokumentasian

\section{Tindakan}

Peneliti memulai proses pembelajaran pada siklus I ini dengan mengucapkan salam dan mengajak semua siswa untuk berdo'a bersama, mengabsensi siswa, menghubungkan pelajaran yang lalu dengan yang sekarang dengan kegiatan tanya jawab. Selanjutnya Siswa mencari informasi tentang materi pembelajaran dengan membaca buku dan memperhatikan penjelasan dari guru yang sedang menjelaskan materi. Kegiatan dilanjutkan guru membentuk kelompok kerja dimana setiap kelompok terdiri dari 6 siswa sehingga ada 6 kelompok, setiap kelompok diberi guru lembar kerja dan di diskusikan oleh anggota kelompok. Kegiatan dilanjutkan guru menekankan kelompok siswa untuk membaca dan meneliti dengan seksama bukunya agar bisa menjawab lembar kerja siswa tersebut, kegiatan dilanjutkan guru mempersilahkan setiap kelompok untuk membacakan hasil kerja kelompok dan kelompok siswa lain mengomentari. Setelah diskusi selesai guru mengklarifikasi hasil kerja siswa secukupnya dan memberikan kuis kepada setiap pertanyaan yang dibuat oleh guru, dimana sumber kuis dibuat guru berdasar LKS dan buku ajar. Pada tahapan terakhir yaitu penutup dimana guru menyuruh siswa untuk mengumpulkan hasil kuis kedepan dan mengajak do'a bersama.

\section{Observasi}

Setelah mengobservasi siswa selama proses pembelajaran di kelas dengan menggunakan instrumen observasi terkait keaktifan siswa dalam mendengarkan dengan seksama penjelasan guru, keaktifan siswa dalam melengkapi jawaban, keaktifan siswa dalam membaca jawaban dan keaktifan siswa dalam mengomentari hasil kerja teman. 


\section{Refleksi}

Selanjutnya peneliti menganggap peningkatan sudah baik dan hanya menyisakan sedikit siswa yang kurang aktif dan nilainya tidak tuntas maka penelitian ini peneliti hentikan

Penerapan Pembelajaran Kooperatif Metode NHT Selama Penelitian

Salah satu tujuan penelitian ini adalah untuk mengetahui penerapan Pembelajaran Kooperatif Metode NHT dalam pembelajaran pada mata pelajaran IPA - Biologi. Metode yang ditempuh selain menggunakan Pembelajaran Kooperatif Metode $N H T$ adalah dengan mengadakan wawancara terhadap siswa mengenai materi yang diajarkan, berkaitan dengan penguasaan awal siswa, inti materi serta kaitannya dengan pengalaman siswa ketika menerima materi pelajaran.

Implementasi model pembelajaran kooperatif tipe NHT pada penelitian ini, dapat dijelaskan sebagai berikut.

\section{Kegiatan awal}

1) Guru mempersiapkan perlengkapan yang diperlukan (media, nomor kepala untuk masing-masing siswa, soal pre test dan post test, angket, LKS, dan lembar pengamatan).

2) Guru melakukan apersepsi sebelum pelajaran dimulai.

3) Soal pre test diberikan kepada siswa untuk mengetahui kemampuan awal siswa.

4) Guru menjelaskan tujuan pembelajaran yang dipelajari kepada siswa.

5) Guru menjelaskan tentang model pembelajaran kooperatif tipe NHT kepada siswa.

\section{Kegiatan inti}

1) Siswa dibagi menjadi 6 kelompok kecil yang anggotanya heterogen terdiri dari 3-4 siswa.

2) Setiap anggota kelompok mendapatkan nomor kepala sesuai dengan jumlah anggotanya.

3) Guru mengajukan pertanyaan dalam bentuk LKS kepada setiap kelompok.

4) Setiap anggota kelompok mempunyai tanggung jawab masingmasing untuk menyelesaikan pertanyaan yang ada di LKS.

5) Semua anggota pada masing-masing kelompok menyatukan pendapatnya/jawabannya untuk diputuskan jawaban yang paling baik.

6) Pastikan semua anggota telah mengetahui jawaban yang telah diputuskan bersama.
7) Setelah selesai diskusi guru memanggil siswa dengan nomor tertentu, kemudian mengundi kelompok mana yang akan memberikan pendapatnya agar tidak berebut.

8) Siswa yang nomornya dipanggil guru mengangkat tangan dan mencoba untuk menjawab pertanyaan yang ada di LKS atau mempresentasikan hasil diskusinya untuk seluruh kelas.

9) Kelompok lain diberi kesempatan untuk berpendapat dan bertanya terhadap kelompok yang baru saja mempresentasikan hasil diskusinya.

10) Selanjutnya, guru dapat memanggil nomor yang berbeda dari kelompok lainnya dan seterusnya sampai semua pertanyaan yang ada di LKS terjawab semua dan siswa menguasai materi yang telah dipelajari.

11) Guru memberikan motivasi kepada kelompok yang belum mendapatkan hasil yang memuaskan dan memberikan reward bagi kelompok yang telah berhasil menjawab dengan baik.

12) Siswa dengan bimbingan guru menyimpulkan materi yang telah dipelajari.

\section{Kegiatan akhir}

1) Untuk mengetahui penguasaan siswa terhadap materi yang telah dipelajari, guru memberikan soal post test kepada siswa.

2) Guru menutup pelajaran dengan berpesan kepada siswa agar mempelajari materi IPA - Biologi untuk pertemuan yang akan datang.

Prosentase minat dan perhatian serta keaktifan siswa merespon penerapan Pembelajaran Kooperatif Metode NHT dalam pembelajaran akan menunjukkan peningkatan dari siklus pertama sampai siklus kedua.

Maka hipotesis yang diajukan yaitu "ada peningkatan perhatian dan minat belajar materi IPA - Biologi melalui penerapan Pembelajaran Kooperatif Metode NHT pada siswa", dapat diterima sebagai satu kebenaran.

Terjadinya peningkatan perhatian dan minat siswa dari siklus pertama hingga siklus kedua tidak lepas dari refleksi guru terhadap kelemahan-kelemahan bentuk dan cara pengajaran yang selama ini diterapkan. Penerapan Pembelajaran Kooperatif Metode NHT dapat menumbuhkan perhatian dan minat siswa dalam proses pembelajaran. Aktivitas siswa yang disertai dengan perhatian intensif akan lebih sukses dan berprestasi. Minat siswa 
terhadap pelajaran juga banyak pengaruhnya terhadap keberhasilan belajarnya.

Meskipun penerapan Pembelajaran Kooperatif Metode NHT ada kelebihan dan kelemahan, namun penggunaannya sangat bermanfaat baik guru maupun siswa. Penerapan Pembelajaran Kooperatif Metode NHT dalam pembelajaran mendorong minat dan perhatian siswa dalam mengikuti proses pembelajaran. Siswa akan lebih aktif dalam mengikuti pembelajaran, dan bagi guru akan lebih mudah dalam mengajar.

\section{Peningkatan Penguasaan Materi dan Hasil Belajar Melalui Penerapan Pembelajaran Kooperatif Metode $\mathrm{NHT}$}

Hasil observasi penelitian mengenai peningkatan penguasaan materi pada pembelajaran IPA - Biologi melalui penerapan Pembelajaran Kooperatif Metode NHT pada siswa ini dilakukan dengan menilai kebenaran jawaban terhadap hasil tes/evaluasi pada setiap akhir kegiatan pembelajaran. Adapun hasil tes/evaluasi siswa dalam setiap siklus yaitu sebagai berikut:

\section{Analisis Deskriptif Hasil Pada Tes Awal}

Sebagai hasil analisis deskriptif terhadap nilai yang diperoleh siswa pada awal kegiatan dapat disajikan pada Tabel 1.

Tabel 1. Statistik Hasil Belajar Pada Tes Awal

\begin{tabular}{|c|l|c|}
\hline No & \multicolumn{1}{|c|}{ Statistik } & $\begin{array}{c}\text { Angka } \\
\text { Statistik }\end{array}$ \\
\hline 1 & Jumlah Siswa & 38 \\
\hline 2 & $\begin{array}{l}\text { Kriteria Ketuntasan } \\
\text { Minimal }\end{array}$ & 70 \\
\hline 3 & Tuntas & 21 \\
\hline 4 & Belum Tuntas & 17 \\
\hline 5 & Nilai Tertinggi & 85 \\
\hline 6 & Nilai Terendah & 40 \\
\hline 7 & Rentang Nilai & 45 \\
\hline 8 & Rata-Rata & $\mathbf{5 6 , 8 2}$ \\
\hline 9 & Simpangan Baku & 10,21 \\
\hline
\end{tabular}

Dari data diatas bila nilai hasil belajar tersebut dikelompokkan berdasarkan kategori (tingkatan), maka diperoleh distribusi nilai seperti yang disajikan pada Tabel 2

.Tabel 2. Distribusi Frekuensi dan Presentase Penguasaan Tes Awal

\begin{tabular}{|c|c|c|c|}
\hline $\begin{array}{c}\text { Rentang } \\
\text { Nilai }\end{array}$ & Kategori & $\begin{array}{c}\text { Frekuensi } \\
\text { (Orang) }\end{array}$ & $\begin{array}{c}\text { Presentase } \\
(\%)\end{array}$ \\
\hline
\end{tabular}

\begin{tabular}{|c|c|c|c|}
\hline $\begin{array}{c}0-35 \\
36-69\end{array}$ & $\begin{array}{l}\text { Sangat } \\
\text { Rendah } \\
\text { Rendah }\end{array}$ & $\begin{array}{c}0 \\
17\end{array}$ & $\begin{array}{c}0 \\
44,74\end{array}$ \\
\hline & $\begin{array}{l}\text { Tidak } \\
\text { Tuntas }\end{array}$ & 17 & 44,74 \\
\hline $\begin{array}{c}70-79 \\
80-89 \\
90-100\end{array}$ & $\begin{array}{l}\text { Sedang } \\
\text { Tinggi } \\
\text { Sangat } \\
\text { Tinggi }\end{array}$ & $\begin{array}{c}11 \\
10 \\
0\end{array}$ & $\begin{array}{c}28,95 \\
26,32 \\
0\end{array}$ \\
\hline & Tuntas & 21 & 55,26 \\
\hline & TOTAL & 38 & 100 \\
\hline
\end{tabular}

\section{Analisis Deskriptif Hasil Tes Akhir Pada Siklus I}

Setelah selesai kegiatan dengan beberapa kali pertemuan maka dilaksanakan tes/evaluasi akhir untuk mengetahui hasil belajar siswa pada mata pelajaran IPA - Biologi dengan penerapan Pembelajaran Kooperatif Metode $N H T$, setelah dilakukan tindakan pada siklus I. Sebagai hasil analisis deskriptif nilai perolehan hasil belajar pada mata pelajaran IPA.

Tabel 3. Statistik Nilai Hasil Belajar Siswa Pada Siklus I

\begin{tabular}{|c|l|c|}
\hline No & \multicolumn{1}{|c|}{ Statistik } & Angka Statistik \\
\hline 1 & Jumlah Siswa & 38 \\
\hline 2 & $\begin{array}{l}\text { Kriteria Ketuntasan } \\
\text { Minimal }\end{array}$ & 70 \\
\hline 3 & Tuntas & 28 \\
\hline 4 & Belum Tuntas & 10 \\
\hline 5 & Nilai Tertinggi & 90 \\
\hline 6 & Nilai Terendah & 55 \\
\hline 7 & $\begin{array}{l}\text { Rentang Nilai } \\
\text { (Jangkauan) }\end{array}$ & 35 \\
\hline 8 & Rata-Rata (Mean) & $\mathbf{6 8 , 8 4}$ \\
\hline 9 & Simpangan Baku & 9,32 \\
\hline
\end{tabular}

Bila nilai penguasaan siswa seperti yang ditunjukkan pada Tabel 3 kemudian selanjutnya dikelompokkan ke dalam beberapa kategori tingkatan, maka distribusi frekuensi dan presentase nilai penguasaan siswa hasil belajar pada mata pelajaran IPA - Biologi dapat diperlihatkan pada Tabel 4 berikut.

Tabel 4. Distribusi Frekuensi dan Presentase Penguasaan Siklus I

\begin{tabular}{|c|l|c|c|}
\hline $\begin{array}{c}\text { Rentang } \\
\text { Nilai }\end{array}$ & Kategori & $\begin{array}{c}\text { Frekuensi } \\
\text { (Orang) }\end{array}$ & $\begin{array}{c}\text { Presentas } \\
\text { e (\%) }\end{array}$ \\
\hline $\begin{array}{c}0-35 \\
36-69\end{array}$ & $\begin{array}{l}\text { Sangat } \\
\text { Rendah } \\
\text { Rendah }\end{array}$ & 0 & 0 \\
10 & 26,32 \\
\hline
\end{tabular}




\begin{tabular}{|c|l|c|c|}
\hline & Tidak & 10 & 26,32 \\
\hline Tuntas & Sedang & 14 & 46,84 \\
$70-79$ & Tinggi & 12 & 31,58 \\
$80-89$ & Sangat & 2 & 5,26 \\
$90-100$ & Tinggi & $\mathbf{2 8}$ & $\mathbf{7 3 , 6 8}$ \\
\hline & Tuntas & $\mathbf{3 8}$ & $\mathbf{1 0 0}$ \\
\hline & TOTAL & $\mathbf{2}$ \\
\hline
\end{tabular}

Analisis Deksriptif Hasil Tes Akhir Pada Siklus II

Setelah dilakukan proses pembelajaran pada kegiatan siklus II maka diperoleh analisis deskriptif dari penguasaan materi dalam bentuk nilai hasil belajar siswa, seperti yang disajikan pada Tabel 5.

Tabel 5. Statistik Nilai Hasil Belajar Siswa Pada Siklus II

\begin{tabular}{|c|l|c|}
\hline No & \multicolumn{1}{|c|}{ Statistik } & Angka Statistik \\
\hline 1 & Jumlah Siswa & 38 \\
\hline 2 & $\begin{array}{l}\text { Kriteria Ketuntasan } \\
\text { Minimal }\end{array}$ & 70 \\
\hline 3 & Tuntas & 35 \\
\hline 4 & Belum Tuntas & 3 \\
\hline 5 & Nilai Tertinggi & 95 \\
\hline 6 & Nilai Terendah & 65 \\
\hline 7 & $\begin{array}{l}\text { Rentang Nilai } \\
\text { (Jangkauan) }\end{array}$ & 30 \\
\hline 8 & Rata-Rata (Mean) & $\mathbf{7 5 , 7 8}$ \\
\hline
\end{tabular}

\section{TINGKAT KETUNTASAN BELAJAR SISWA}

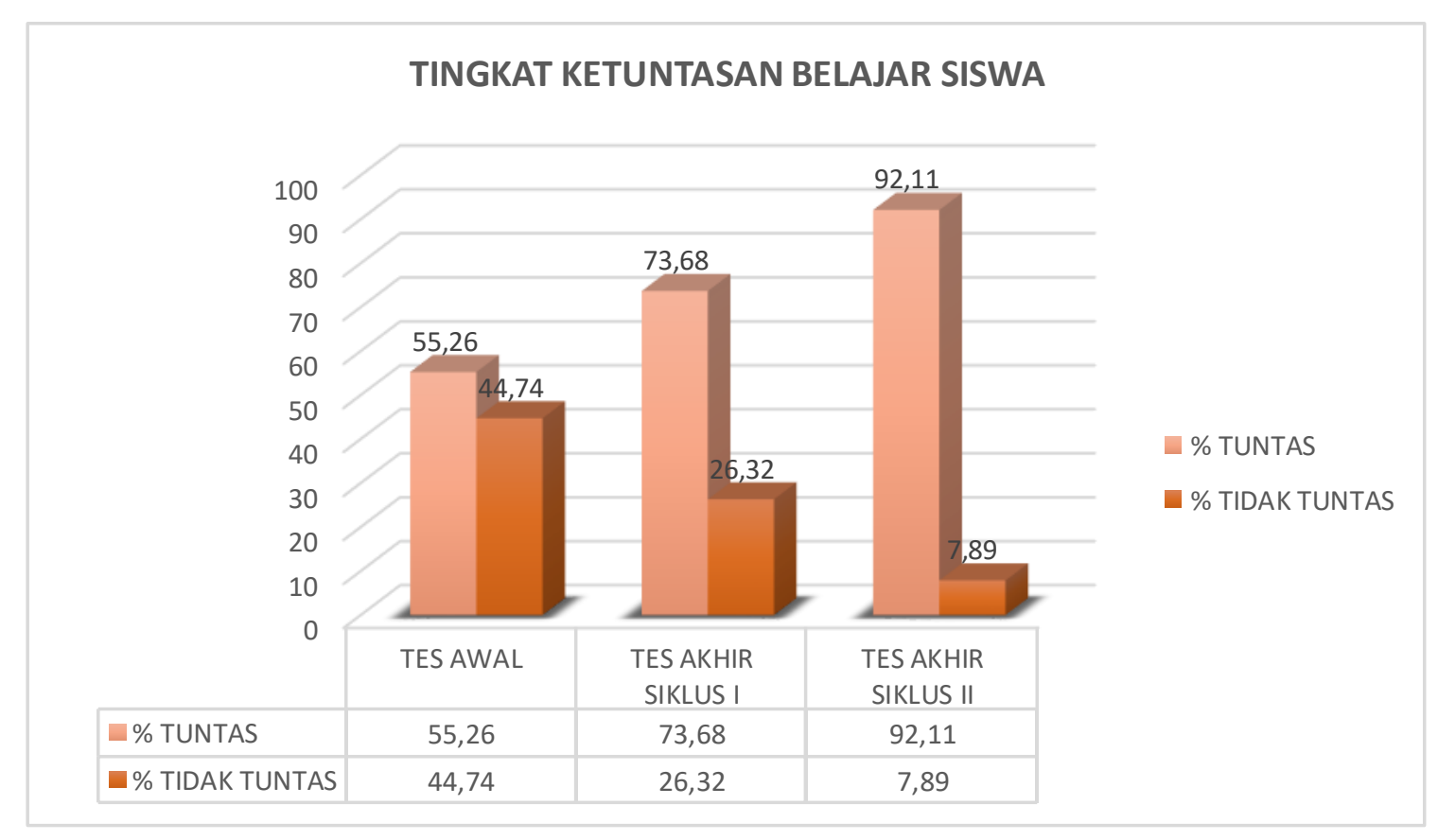

Gambar 1. Diagram Batang Tingkat Ketuntasan Belajar Siswa

\begin{tabular}{|l|l|c|}
\hline 9 & Simpangan Baku & 8,46 \\
\hline
\end{tabular}

Dari hasil belajar siswa seperti yang ditunjukkan pada Tabel 5 dapat dikelompokkan menjadi kategorisasi sebagai distribusi frekuensi dan presentasi nilai hasil belajar siswa pada siklus II, seperti yang ditunjukkan pada Tabel 6 berikut.

Tabel 6. Distribusi Frekuensi dan Presentase

\begin{tabular}{|c|c|c|c|}
\hline $\begin{array}{l}\text { Rentang } \\
\text { Nilai }\end{array}$ & Kategori & $\begin{array}{c}\text { Frekuensi } \\
\text { (Orang) }\end{array}$ & $\begin{array}{c}\text { Presentas } \\
\text { e }(\%)\end{array}$ \\
\hline \multirow[t]{2}{*}{$\begin{array}{c}0-35 \\
36-69\end{array}$} & $\begin{array}{l}\text { Sangat } \\
\text { Rendah } \\
\text { Rendah }\end{array}$ & $\begin{array}{l}0 \\
3\end{array}$ & $\begin{array}{c}0 \\
7,89\end{array}$ \\
\hline & $\begin{array}{l}\text { Tidak } \\
\text { Tuntas }\end{array}$ & 3 & 7,89 \\
\hline \multirow[t]{3}{*}{$\begin{array}{c}70-79 \\
80-89 \\
90-100\end{array}$} & $\begin{array}{l}\text { Sedang } \\
\text { Tinggi } \\
\text { Sangat } \\
\text { Tinggi }\end{array}$ & $\begin{array}{c}7 \\
20 \\
8\end{array}$ & $\begin{array}{l}18,42 \\
52,63 \\
21,05\end{array}$ \\
\hline & Tuntas & 35 & 92,11 \\
\hline & TOTAL & 38 & 100 \\
\hline
\end{tabular}

Tingkat ketuntasan belajar siswa pada Gambar 1 berikut. 
Dari Gambar 1 menunjukkan tingkat ketuntasan belajar siswa yang terjadi peningkatan. Dimana hal ini menunjukkan hasil belajar siswa setelah dilakukan tindakan kelas baik pada siklus I maupun siklus II terjadi peningkatan yang sangat signifikan.

Secara umum dapat disimpulkan bahwa hasil belajar siswa setelah dilakukan tindakan kelas khususnya penerapan pembelajaran dengan Pembelajaran Kooperatif Metode NHT dalam materi pelajaran IPA - Biologi telah terjadi peningkatan yang sangat signifikan.

Selanjutnya tingkat hasil belajar siswa pada siklus I dan siklus II sebagaimana yang terdapat pada Gambar 2 berikut.

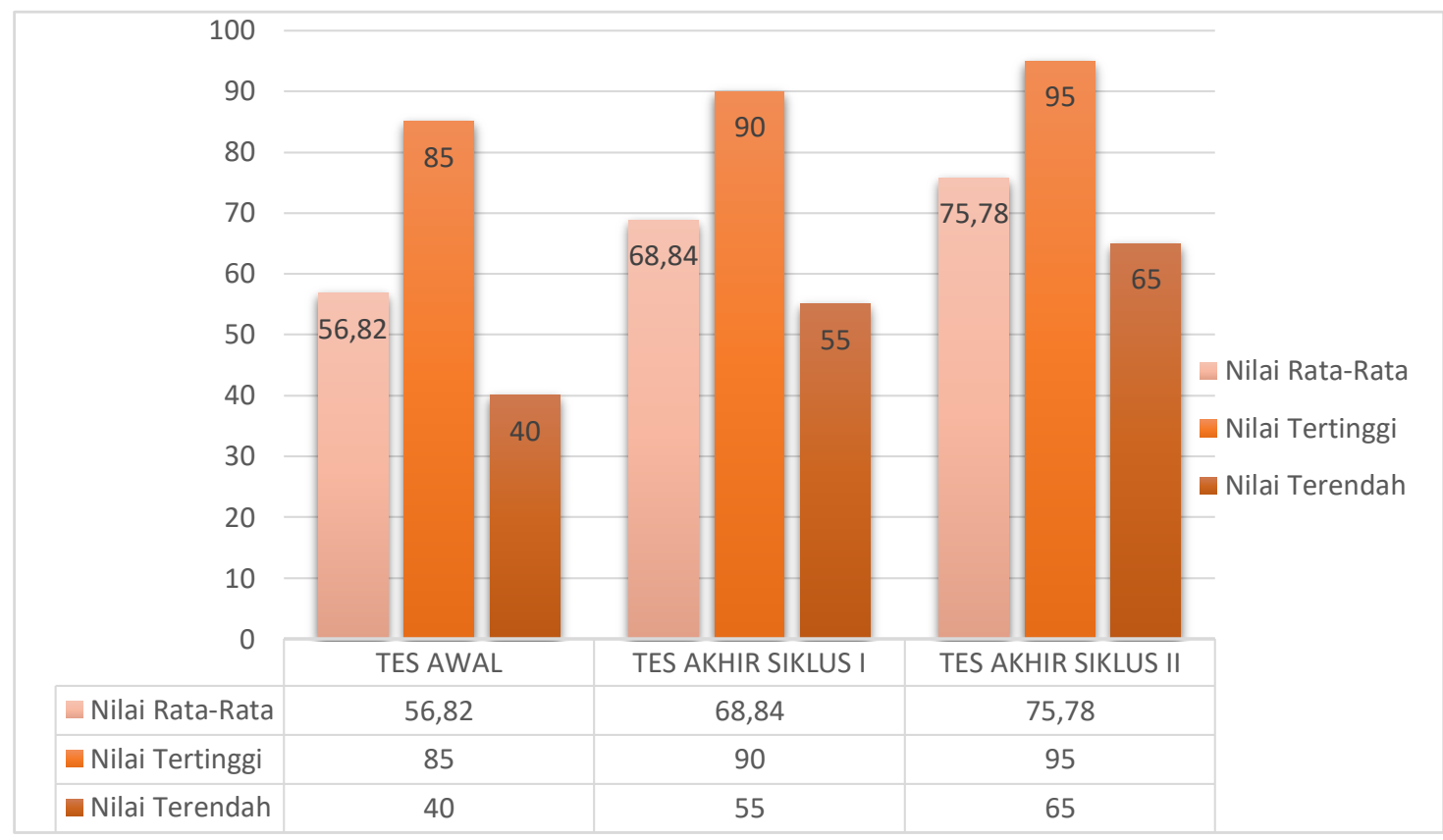

Gambar 2. Tingkat Hasil Belajar Siswa

Berdasarkan keseluruhan pembahasan di atas maka dapat diambil suatu kesimpulan terhadap hipotesis yang diajukan, yaitu "Adanya kenaikan penguasaan materi dalam pembelajaran IPA - Biologi setelah diberikan tindakan kelas dengan Pembelajaran Kooperatif Metode NHT " dapat diterima sebagai suatu kebenaran.

Pada pra siklus atau kegiatan awal sebelum siklus I dilakukan, guru menjelaskan materi pada siswa dengan menggunakan metode mengajar ceramah bervariasi. Berdasarkan hasil penelitian tindakan pra siklus diketahui hasil belajar siswa belum memuaskan. Ketuntasan belajar klasikal baru mencapai $55,26 \%$ dengan nilai rata-rata 56,82.

Terdapat peningkatan signifikan pada hasil belajar siklus I menunjukkan adanya kemajuan walaupun belum memuaskan namun terlihat ada peningkatan dari siklus I. Pada siklus I rata-rata nilai belajar sudah tercapai, namun belum melebihi angka 70, karena ketuntasan pada siklus I baru mencapai 73,68\% dengan nilai rata-rata 68,84.

Pada siklus II ketuntasan belajar dan ratarata nilai sudah tercapai, karena pada siklus II ini ketuntasan sudah mencapai $92,11 \%$ dengan nilai rata-rata 75,78. Maka pembelajaran IPA Biologi menggunakan Pembelajaran Kooperatif Metode NHT berpengaruh terhadap penguasaan materi terhadap siswa, hal ini dapat terlihat dengan adanya peningkatan pada ketuntasan belajar perorangan dan ketuntasan belajar.

Jadi hasil penelitian yang dilakukan peneliti sesuai dengan teori yang ada sehingga hipotesis tindakan yang menyatakan penerapan Pembelajaran Kooperatif Metode NHT dapat meningkatkan hasil belajar mata pelajaran IPA Biologi dapat diterima. 


\section{PENUTUP}

Setelah menguraikan pembahasanpembahasan di bab terdahulu maka dalam bab ini akan disimpulkan bahwa:

a. Penerapan Pembelajaran Kooperatif Metode NHT pada pembelajaran IPA - Biologi dilakukan dengan cara guru menerangkan materi kemudian melakukan Tanya jawab, selanjutnya guru memberikan soal kepada masing-masing siswa untuk dijawab, hasil jawaban tersebut didiskusikan dengan teman sebangkunya untuk ditemukan jawaban terbaik, dari hasil kerja pasangan tersebut kemudian dipadukan dengan pasangan lain sehingga setiap kelompok ada empat siswa untuk mendiskusikan hasil jawaban terbaik, dari jawaban kelompok empat siswa kemudian digabungkan dengan kelompok empat yang lain sehingga setiap kelompok ada delapan siswa untuk mendikusikan jawaban soal yang terbaik, hasil dari kelompok tersebut untuk didiskusikan dalam kelas.

b. Penggunaan Pembelajaran Kooperatif Metode NHT terbukti dapat meningkatkan ketuntasan belajar siswa pada pelajaran IPA - Biologi. Penggunaan Pembelajaran Kooperatif Metode NHT dalam pembelajaran mendorong minat dan perhatian siswa dalam mengikuti proses pembelajaran. Siswa akan lebih aktif dalam mengikuti pembelajaran, dan bagi guru akan lebih mudah dalam mengajar. Pada pra siklus yang menggunakan metode ceramah, ketuntasan belajarnya belum begitu baik yaitu $55,26 \%$. Adapun pada siklus I dan II yang menggunakan Pembelajaran Kooperatif Metode NHT , menunjukkan peningkatan yang lebih baik yaitu 73,68\% pada siklus I dan $92,11 \%$ pada siklus II.

c. Penggunaan Pembelajaran Kooperatif Metode NHT terbukti dapat meningkatkan hasil belajar siswa pada pelajaran IPA Biologi. Adapun pada siklus I dan II yang menggunakan Pembelajaran Kooperatif Metode NHT , menunjukkan peningkatan yang lebih baik pada nilai rata-rata siswa yang naik dari 56,82 pada pra siklus dan menjadi 68,84 pada siklus I, kemudian naik menjadi 75,78 pada siklus II.

Jadi ada peningkatan penguasaan materi dalam bentuk hasil belajar dan ketuntasan belajar siswa setelah diberikan tindakan berupa penerapan Pembelajaran Kooperatif Metode NHT dalam pembelajaran IPA - Biologi.

\section{DAFTAR PUSTAKA}

Abdurrahman, Mulyono, Pendidikan Bagi Anak Berkesulitan Belajar, Jakarta: Rineka Cipta, 2000

Arikunto, Suharsimi, Dasar-Dasar Evaluasi Pendidikan, Jakarta: Bumi aksara, 2001

Basrowi dan Suwandi, Prosedur Penelitian Tindakan Kelas, Bogor: Penerbit Ghalisa Indonesia, 2008

Crow, Lester D. and Alice Crow, Human Development and Learning, New York: American Book Company, 2002

Lie, Anita, Cooperative Learning; Mempraktekkan Cooperative Learning di Ruang-Ruang Kelas, Jakarta: Gramedia, 2005

Margono, Metodologi Penelitian Pendidikan, Jakarta: Rineka Cipta, 2000

Meier, Dave, The Accelerated Learning Handbook: Panduan Kreatif dan Efektif Merancang Program Pendidikan dan Pelatihan, Bandung: Kaifa, 2003

Mulyasa, E, Kurikulum Berbasis Kompetensi, Bandung: Rosdakarya, 2004

Reynolds, David dan Daniel Muijs, Effective Teaching Evidence and Practice, Yogyakarta: Pustaka Pelajar, 2008

Sagala, Saeful, Konsep dan Makna Pembelajaran, Bandung: Alfa Beta, 2003

Slameto, Belajar Dan Faktor-Faktor Yang Mempengaruhinya, Jakarta: Rineka Cipta, 2006.

Solihatin, Etin, Cooperative Learning Analisis Model Pembelajaran IPA, Jakarta: Bumi Aksara, 2008

Subyantoro, Penelitian Tindakan Kelas, Semarang: CV. Widya Karya, 2009

Sudijono, Anas, Evaluasi Hasil Belajar, Jakarta: PT. Raja Grafindo Persasda, 2011

Sudjana S. Strategi Pembelajaran Partisipatif, Jakarta: Rineka Cipta, 2008

Sukmadinata, Nana Syaodih, Model Penelitian Pendidikan, Bandung: Remaja Rosda Karya, 2005

Suprijono, Agus, Cooperative Learning Teori Dan Aplikasi PAIKEM, Yogyakarta: Pustaka Pelajar, 2010

Syah, Muhibbin, Psikologi Pendidikan Dengan Pendekatan Baru, Bandung: Remaja Rosdakarya, 2010

Trianto, Model-Model Pembelajaran Inovatif Berorientasi Konstrutivistik, Jakarta: Prestasi Pustaka, 2007. 
Jurnal TIK dalam Pendidikan, Vol. 7 No. 1 Juni 2020, p-ISSN: 2355-4983, e-ISSN: 2407-7488

Winkel, W.S., Psikologi Pendidikan dan Evaluasi Belajar, Jakarta: Gramedia, 2003
Wiriatmadja, Rochiarti, Model Penelitian

Tindakan Kelas, Bandung: PT Remaja Rosda Karya, 2006 